\title{
Influence of Some Novel Insecticides on Physiological and Biological Aspects of Spodoptera littoralis (Boisduval)
}

\author{
Madeha E.H. El-Dewy 1
}

\begin{abstract}
Chloranitraniliprole, pyridalyl, indoxacarb, emamectin-benzoate and spinetoram are promising insecticides in the Lepidopteran insects control. The effect of the sublethal concentrations $\left(\mathrm{LC}_{25}\right)$ of these compounds on some physiological and biological aspects of the $4^{\text {th }}$ larval instar of Spodoptera littoralis (Boisd.) laboratory strain using feeding technique was investigated. Based on the $\mathrm{LC}_{50}$ values, emamectin-benzoat was the most effective insecticide followed by indoxacarb while spinetoram was the least toxic one. Chloranitraniliprole and pyridalyl exhibited a moderate toxic effect. The tested insecticides at $\mathbf{L C}_{25}$ significantly decreased the consumption index, relative growth rate and efficiency of converting ingested and digested food into body tissue, while did not significantly affect the approximate digestibility. All the tested insecticides significantly prolonged the larval duration and decreased the pupal duration of S.littorallis without significant differences among them. As latent effects on survived larvae, these insecticides significantly decreased the percentages of normal pupae, adult emergence, fecundity and fertility of the pest as compared with control. Spinetoram was the least effective on the biological aspects. Pyridalyl, chloranitraniliprole, emamectin-benzoate and indoxacarb could be used as important tools in integrated management programs of $S$. littoralis.
\end{abstract}

Key words: Novel insecticides, physiological aspects, biological aspects, Spodoptera littoralis

\section{INTRODUCTION}

The noctuid Spodoptera littoralis (Boisduval) is a major polyphagous pest, widely distributed throughout Africa, Mediterranean area, Europe and several parts of Asia (Azab et al., 2001). Over the past 25 years, the extensive use of broad-spectrum insecticides against $S$. littoralis has led to the development of its resistance to many registered insecticides and caused serious problems in environment components and their natural balance between pests and the natural enemies (Abo Elghar et al., 2005; Adyin and Gurkan, 2006). Therefore, scientists and workers in the field of insect control are seeking alternatives that are effective against this pest, safe to humans, environmental friendly and compatible with integrated pest management (IPM). Among the most promising alternative to the conventional insecticides are Avermectins, Spinosyns,
Oxadiazines, Pyridalyl and Anthronilic diamides with selective properties that are designed to act on specific biochemical sites of physiological processes of the target pests. Also, they have the potential for crop protection against economics pests with low hazard to environment component and natural enemies (Foster et al., 2003; Michaud and Grant, 2003; Sakamoto et al., 2005 and Dinter et al., 2008). Pyridalyl is a novel insecticide exerts excellent control against Lepidopteran and Thysanopteran pests on cotton, vegetables and fruits (Sakamato and Umedo, 2003). Chlorantranilifrole (Rynaxypyr) is a novel compound belonging to anthronilic diamides, featuring a novel mode of action by activating the insect ryanodine receptors, it stimulates the release and depletion of intracellular calcium stores from the sarcoplasmic reticulum of muscle cells, causing impaired muscle regulation, paralysis and ultimately death of sensitive species (Cordova et al., 2006), chlorantraniliprole has an excellent profile of safety to beneficial arthropods (Dinter et al., 2008). Indoxacarb represents a new class of insecticides (Oxidiazines, with its stomach and contact action (Wise et al., 2006. It blocks the movement of sodium ions into the nervous system, resulting in paralysis and death of the pest. Emamectin-benzoate is a novel semi-synthetic avermectin acts by interfering with the action of gamma aminobutyric acid (GABA), It blocks post-synaptic potentials of neuromuscular production and inhibit feeding (Pienkowski and Mehring, 1983 and Wright, 1984). Spinetoram is a new generation of spinosyn group. It causes excitation of the insect nervous system by altering the function of nicotinic and GABA gated ion channels. (Crouse and Sparks, 1998). Feeding and reproduction of any insect are very closely related to nutritional status, where the amount and quality of food consumed by a larvae influence its performance, growth rate, development time, finally its body weight and survival (Slansky and Scriber, 1985). Thus, this study aimed to evaluate the sublethal effects of pyridalyl, chloranitraniliprole, indoxacarb, emamectin-benzoate and spinetoram on some physiological aspects and biological aspects of the $4^{\text {th }}$ larval instar of S.littoralis .

${ }^{1}$ Plant Protection Research Institute, Agricultural Research

Center, Giza, Egypt

Corresponding address: madeha.dewy@yahoo.com

Received May 2, 2017, Accepted June 5, 2017 


\section{MATERIALS AND METHODS}

\section{Insecticides}

Commercial pyridalyl (Pleo 50\% EC, Sumitomo Chemical Co.), anthranilic diamide insecticide, chloranitraniliprole, (Coragen, 20\% SC, Du Pont Co.), indoxacarb (Avaunt, 15\% EC, Du Pont Co.), emamectin-benzoate (Proclaim, 5\% SG, Syngenta Co.) and spinetoram (Radiant, 12\% SC, Daw Agro Sciences Co.) were used in this study.

\section{Insect rearing}

The laboratory strain of Spodoptera littoralis (Boisduval) was reared in the laboratory of Sakha Agricultural Research Station on Caster bean leaves under constant laboratory conditions of $25 \pm 2{ }^{\circ} \mathrm{C}$ and 65 \pm 5 R.H. according to (El-Defrawi et al., 1964).

\section{Toxicological studies}

To study the toxicity of emamectin benzoate, spinetoram, pyridalyl, chlorantaniliprole and indoxacarb against the newly moulted $4^{\text {th }}$ larval instar of laboratory strain, a serial of aqueous concentrations of each compound was prepared. The leaf- dipping technique was adopted according to Abo Elghar et al. (1994), where fresh castor bean leaves were dipped for 10 seconds in one of the prepared concentrations. The treated leaves had dried under laboratory conditions before being offer to $S$. littoralis larvae. Hundred larvae distributed in ten replicates (10 larvae/replicate), were used for each concentration. Larvae were fed on leaves immersed in only water as a control. Newly moulted $4^{\text {th }}$ larval instar were fed on the treated leaves in a glass jar covered with muslin for $24 \mathrm{~h}$ for the tested compound. The treated leaves were replaced by another untreated ones. Mortality percentages were recorded after 24, 48 and $72 \mathrm{~h}$ of treatment. The mortality was corrected using Abbott's formula (Abbott, 1925). The $\mathrm{LC}_{25}, \mathrm{LC}_{50}$ and slope values of the tested compounds were calculated using the equation of Finney(1971), by software Program.

\section{Physiological studies:}

Caster bean leaves were soaked in $\mathrm{LC}_{25}$ of each insecticide (which calculated after $72 \mathrm{~h}$ of exposure for 10 seconds. The newly moulted $4^{\text {th }}$ larval instar of $S$. littoralis were starved for three hours before used in the tests to make insure on empty intestine (El-Malla and Radwan, 2008) and weighted. Five replicates of 10 larvae/each were allowed to fed on the treated leaves for $24 \mathrm{~h}$, then provided daily with untreated leaves for three successive days (experimental period 4 days). Dead larvae were excluded, while the fresh weights of survivors, faeces and uneaten treated leaves in each replicate were daily recorded. Fresh leaves were kept in a similar rearing jar under the same conditions to estimate the natural loss of moisture, which was used for calculating the corrected weight of consumed fresh leaves. Food consumption and utilization were calculated according to the equation given by Waldbauer (1968) and Slansky and Scriber (1982) as follows:

1. Consumption index $(\mathrm{CI})=\mathrm{C} / \mathrm{TA}$

2. Relative growth rate $(\mathrm{RGR})=(\mathrm{G} / \mathrm{TA}) \times 100$.

3. Approximate digestibility $(\mathrm{AD})=[\mathrm{C}-\mathrm{F}) / \mathrm{C}] \times 100$

4. Efficiency of conversion of ingested food to body tissue $(\mathrm{ECI})=(\mathrm{G} / \mathrm{C}) \times 100$

Where:

$\mathrm{C}=$ Fresh weight of leaves consumed

$\mathrm{T}=$ Duration of feeding period

A $=$ Mean fresh weight of the larva during the feeding period.

$\mathrm{G}=$ Fresh weight gain of the larvae.

$\mathrm{F}=$ Faeces weight during the feeding period.

During the experiment, the calculated mean weight (fresh) of the consumed treated leaves corrected as follows:

The corrected weight of leaves consumed [1-a/2][W$(\mathrm{L}+\mathrm{bL})]$

where:

a $=$ The ratio of loss of water to the initial weight of leaf

b $=$ The ratio of loss of water to final weight of leaf

$\mathrm{w}=$ Weight of food introduced

$\mathrm{L}=$ Weight of uneaten food.

$\mathrm{T}$ =Feeding period.

Antifeedant index were recorded according to Pavela et al. (2008) 100

The feeding deterrent index $(\mathrm{FDI})=[(\mathrm{C}-\mathrm{T}) /(\mathrm{C}+\mathrm{T})] \mathrm{x}$

Where: $\mathrm{C}$ and $\mathrm{T}$ are the control and treated leaves consumed by insect.

\section{Biological studies}

Caster bean leaves were soaked in $\mathrm{LC}_{25}$ of each insecticide, which was calculated after $72 \mathrm{~h}$. Two hundred larvae were used for each insecticide.The larvae were placed in a glass jar and provided with the treated leaves for $24 \mathrm{~h}$ and then the survived larvae were transferred to jars containing fresh untreated leaves and checked daily to determine larval duration, pupal duration, percentages of normal pupae, deformed pupae and adult emergence. One female and one male of emerged adults were placed together, in wood box to maximize successful mating and provided with a piece 
of cotton soaked in $10 \%$ sugar solution as a source of food for each treatment. To determine the fertility ( egg hatchability\%), three or four patches having not less than 100 eggs were collected during the first three successive days of oviposition and incubated under the laboratory conditions until hatching and the neonates number was recorded, also fecundity (no. of eggs/female) and fecundity percentage was calculated according to Crystal and Lachance (1963) as follows:

$$
\% \text { Fecundity }=\frac{\text { No.eggs } / \text { treated female }}{\text { No.eggs } / \text { untreatedfemale }} \times 100
$$

\section{Statistical analysis:}

All data were subjected to analysis of variance (ANOVA) through SPSS computer program (2004) and the means values were compared using Duncan's multiple range test (1955).

\section{RERSULTS AND DISCUSSION}

1.Susceptibility of Spodoptera littoralis to the tested insecticides:

The results presented in Table (1) revealed that emamectin benzoate exerts excellent control of $4^{\text {th }}$ larval instar of $S$. littoralis followed by indoxacarb. Spinetoram was the least effective after different exposure times. The descending order of larvicidal activity of the tested compounds. Emamectin-benzoate, indoxacarb, Pyridalyl, Chloranitraniliprole and spinetoram, where the $\mathrm{LC}_{50}$ values were $0.46,4.17$, $13.01,15.0$, and $48.52 \mathrm{mg}$ a.i./l. after $48 \mathrm{~h}$. Their toxicity increased dramatically after $72 \mathrm{~h}$ to be $0.364,1.58$, $10.16,10.03$, and $13.75 \mathrm{mg}$ a.i./1.,respectively. The present results are in parallel with that of Abdel Rahim et al.,2009;El-dewy 2013; El-Naggar 2013 and ELSheikh, 2015), where they reported that emamectinbenzoate was the most effective compound against $4^{\text {th }}$ larval instars' of $S$. littoralis, also El-Geddawy et al.,2014 stated that emamectin-benzoat is the most potent compound followed by indoxacarb and spinetoram of $S$. littorallis.

2- Effect of the tested insecticides on the food utilization and nutrition indicates of Spodoptera littoralis (Boisd.):

Three criteria have been used in judging the utilization of the food by S.littoralis larvae the digestibility of the food, the conversion of ingested or digested food into body tissue and the rate of consumption. The nutrition indices and food utilization were recorded and the data are presented in Table (2). It is clear that the larvae fed on treated leaves with $\mathrm{LC}_{25}$ of chloranitaniliprole, pyridalyl, indoxacarb, emamectinbenzoate and spinetoram showed significant decrease in their weight compared to control. Moreover, the antifeedant index indicated that emamectin-benzoate and chloranitraniliprole were the highest inhibitiors of feeding recording 36.72 and $32.05 \%$, respectively. With respect to the consumption index (CI) and relative growth rate (RGR), both of emamectin-benzoate and chloranitraniliprole recorded high significant reduction in (CI) and (RGR) compared with control followed by pyridalyl, indoxacarb and spinetoram, without significant differences between them. Antifeedant and growth activity inhibitor reduce pest damage by products but it could be without killing the pest. Woodering et al. 1978 and Sundaramurthy, 1977 revealed that the amount of growth reduction was proportional in general to reduce food consumption. Concerning approximate digestibility and converting ingested or digested food $\%$ to body tissue, the results presented in Table (2) showed that the digestion of food ingested by larvae was not significantly affected by the tested insecticides.

Table 1. Toxicity of some novel insecticides against $4^{\text {th }}$ larval instar of Spodoptera littoralis (Boisd.) by dipping technique at different exposure times

\begin{tabular}{lcccccc}
\hline \multirow{2}{*}{ Insecticides } & \multirow{2}{*}{ Time (hrs) } & $\mathbf{L C}_{\mathbf{2 5}} \mathbf{( p p m )}$ & $\mathbf{L C}_{\mathbf{5 0}} \mathbf{( p p m )}$ & \multicolumn{2}{c}{ Confidence limits } & \multirow{2}{*}{ Slope values \pm SE } \\
\hline \multirow{2}{*}{ Chloranitraniliprole } & 48 & 15.0 & 27.72 & 45.34 & 22.99 & $3.22 \pm 0.88$ \\
& 72 & 1.42 & 10.03 & 12.44 & 6.57 & $1.97 \pm 0.234$ \\
\hline \multirow{2}{*}{ Pyridalyl } & 24 & 24.83 & 37.88 & 42.18 & 33.59 & $3.68 \pm 0.45$ \\
& 48 & 8.24 & 13.01 & 15.2 & 10.41 & $3.41 \pm 0.59$ \\
& 72 & 5.17 & 10.16 & 12.38 & 7.10 & $3.12 \pm .62$ \\
\multirow{2}{*}{ Indoxacarb } & 24 & 9.74 & 16.46 & 18.75 & 14.66 & $2.96 \pm 0.313$ \\
& 48 & 1.21 & 4.17 & 5.34 & 3.04 & $1.2 \underline{5+0.17}$ \\
\multirow{2}{*}{ Emamectin-benzoate } & 72 & 0.677 & 1.58 & 2.06 & 1.00 & $1.83 \pm 0.32$ \\
\hline \multirow{2}{*}{ Spinetoram } & 48 & 0.46 & 1.35 & 1.67 & 1.12 & $1.45 \pm 0.22$ \\
& 72 & 0.116 & 0.364 & 0.519 & 0.15 & $1.36 \pm 0.33$ \\
\hline
\end{tabular}


Both efficiency of converting ingested (ECI) and digested food (ECD) decreased for to all the tested insecticides compared with control, where ECI is an overall measure of an insect's ability to utilization the ingested food for growth. A drop in ECI indicated that most food is being converted into energy and less is being converting to body tissue (growth). ECD also decreased as the proportion of digested food converted into energy increased and associated with the loss of fitness because of starvation. Decreasing ECI and ECD values indicate that tested insecticides could be elicit some chronic toxicity. From the previous data, all treatment significantly reduced the digestibility. This may be due to the high percent of excretion of food consumption by larvae as compared to control. Generally, emamectin benzoate and chloranitraniliprole were the most effective with decreasing the consumption index, relative growth rate, efficiency of converting ingested and digested food into body tissue, whereas chloranitraniliprole rapidly inhibited the insect feeding and death normally occurs within 24-72 hours. Also, emamectin-benzoate stopped feeding within hours of ingestion and caused death within 48-96 hours. Spinetoram exhibited the least effective in all nutrition indicates and utilization food. Sublethal concentration of pesticides can provide useful information concerning the basic physiological and behavioral responses of the target insect pest and this could be of high important value when new compounds are evaluated for potential application in pest management program (Von Keyserlink, 1988) . The degree of utilization food depends upon the digestibility of the food and the efficiency with which digested food is converted into body material (Sooho and Frankel, 1966). Also, ElShazly (1993) revealed that varied with the digestibility of food and amount of the digestible portion of food which is converted to body substance and metabolized for energy to maintain life. Our results are in conformity with those obtained by Abo El-Ghar 1993 and El-Malla and Radwan, 2008). They reported that growth rate, consumption index, approximate digestibility, efficiency of conversions of either ingested or digested food to body tissue of $S$. littoralis larvae fed on Abamectin and Sumialfa decreased compared to untreated larvae.

On the other hand, Hassan, 2009; El-Naggar 2013; ElSheikh 2015 and Rashwann, 2013) found that chloranitraniliprole, emamectin-benzoate and indoxacarb significantly decreased the nutrition indicates and utilization of food. In addition Chunmei $\mathrm{Xu}$ et al. (2016) showed that cyantraniliprole had markedly antifeedant effects against $4^{\text {th }}$ instar larvae of
Agrotis ipsilon, which relatively decreased the same parameters of nutrition indices and utilization food.

\section{3- Effects of the tested insecticides on some biological aspects of Spodoptera littoralis:}

To determine biological aspects of S. littoralis, the newly moulted of $4^{\text {th }}$ instar larvae were fed on caster bean leaves treated with $\mathrm{LC}_{25}$ of chloranitraniliprole, pyridalyl, indoxacarb, emamectin-benzoate and spinetoram $24 \mathrm{~h}$ and untreated leaves until pupation. The main biological aspects were recorded and the results were presented in Tables (3 and 4).

The results presented in Table (3) showed that all the tested insecticides significantly increased the larval duration which recorded as indoxacarb (23.5 days), chloranitraniliprole (19.0 days) ,pyridalyl (16.5 days) and spinetoram (15.0 days) compared to the control (13.0 days)

In contrary, the tested insecticides decreased the pupal duration without significantly differences among them, while spinetoram significantly prolonged the pupal duration (12 days).

With respect to the latent effects, the data in Table (3) indicated that indoxacarb was the most effective recording (35.0, 9.86 and 71.93\%) compared to control (98.0, 1.45 and $97.44 \%$ ) to percentages of normal pupae, deformed pupae and adult emergence, respectively, followed by pyridalyl (78.88, 12.68, $67.28 \%$ ), and spinetoram $(95.81,0.67,82.76)$. These results are in agreement with the findings of Amer et al. (2012). Abdel-Hafez and Osman (2013) found that emamectin-benzoate and pyridalyl decreased pupal weight, pupation and adult emergence percentages of $S$. littoralis. Also, Chunmei $\mathrm{Xu}$ et al. (2016) stated that sublethal doses of cyantraniliprole at $\mathrm{LC}_{5}, \mathrm{LC}_{20}$, and $\mathrm{LC}_{40}$ levels prolonged larval and pupal duration and extended mean generation time and total preovipositional period of Agrotis ipsilon.

With regard to fecundity and percentages of fecundity and eggs hatchability, the results presented in Table (4) indicated that indoxacarb and pyridalyl had noticeably decreased the mean numbers of eggs laid by adult female (fecundity), also eggs hatchability (fertility) was significantly decreased in the offspring generation after the parent fourth instar larvae treated with indoxacarb recording 443.43 eggs/female, $20.67 \%$ fecundity and $66.11 \%$ fertility followed by pyridalyl (816.67 eggs/female, $38.07 \%$ fecundity and $67.28 \%$ fertility as compared to control (2145.0 eggs/female, $100 \%$ fecundity and $97.44 \%$ fertility. 


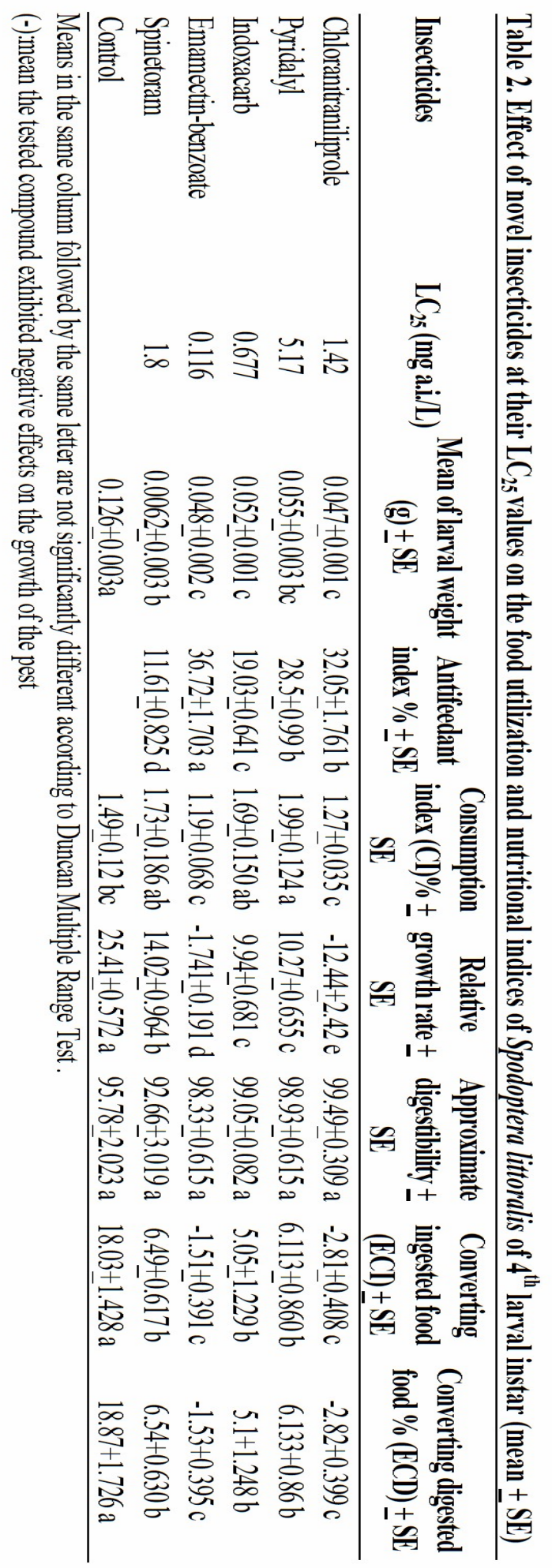


Table 3. Some biological aspects for survived $4^{\text {th }}$ larval instar of Spodoptera littoralis laboratory strain when fed on treated castor bean leaves with $\mathrm{LC}_{25}$ value of some novel insecticides

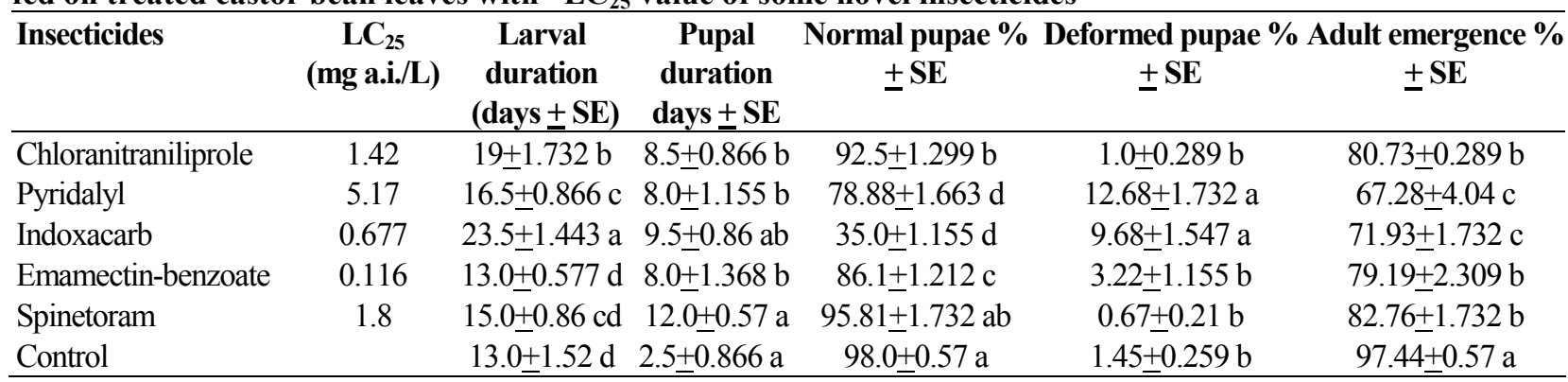

Means in the same column followed by the same letter are not significantly different according to Duncan Multiple Range Test .

Table 4. Effect of the tested insecticides on number of egg per femal, Fecundity\% and egg hatchability of Spodoptera littoralis

\begin{tabular}{lcccc}
\hline Insecticides & $\mathbf{L C}_{\mathbf{2 5}} \mathbf{( m g}$ a.i./L) & No. of eggs/female $\pm \mathbf{S E}$ & Fecundity $\% \pm \mathbf{S E}$ & Egg hatchability $+\mathbf{S E}$ \\
\hline Chloranitraniliprole & 1.42 & $1705.36+11.547 \mathrm{c}$ & $93.43+1.73 \mathrm{~b}$ & $76.8+3.64 \mathrm{~b}$ \\
Pyridalyl & 5.17 & $816.67+9.238 \mathrm{e}$ & $38.07+4.62 \mathrm{~d}$ & $67.28+1.443 \mathrm{c}$ \\
Indoxacarb & 0.677 & $443.43+23.09 \mathrm{f}$ & $20.67+2.88 \mathrm{e}$ & $66.11+4.04 \mathrm{c}$ \\
Emamectin-benzoate & 0.116 & $1307.94+9.82 \mathrm{~d}$ & $60.98+8.66 \mathrm{c}$ & $77.85+4.04 \mathrm{c}$ \\
Spinetoram & 1.8 & $2004.17+8.08 \mathrm{~b}$ & $79.5+5.19 \mathrm{~b}$ & $82.43+1.732 \mathrm{~b}$ \\
Control & & $2145.00+25.98 \mathrm{a}$ & $100 \mathrm{a}$ & $97.44+0.866 \mathrm{a}$ \\
\hline
\end{tabular}

Means in the same column followed by the same letter are not significantly different according to Duncan Multiple Range Test (1955).

Spinetoram was the lowest effective one giving (2004.17 eggs/female, $79.5 \%$ fecundity and $82.43 \%$ fertility. The reduction in fecundity may be due to disfunction of maturation of an insect egg which depend on the materials that are synthesized by the ovary in suit which includes protein, lipids and carbohydrates, all of which required for embryonic structure (Shaurub et al., 1998). On the other hand, reduction in feeding activity of the insect may reduce normal development, weight gain, fecundity and increase mortality (Van Duyn, 1971).

.These results are in agreement with that obtained by many investigators. Abdel-Rahim et al., 2009) who found that emamectin benzoate and pyridalyl at $\mathrm{LC}_{50}$ increased the larval and pupal duration of $S$. littoralis and decreased fecundity and fertility. Meanwhile, ElNaggar, 2013 and El-Zahi , 2013 repoted that pyridalyl was more effective against $4^{\text {th }}$ larval instar of S. littoralis than emamectin benzoate on the most biological aspects compared to control.

\section{CONCLUSION}

From the obtained results, it could be concluded that the novel insecticides, pyridalyl, chloranitaniliprole, emamectin-benzoate and indoxacarb had high effect on $S$. littoralis, where their sublethal concentration $\left(\mathrm{LC}_{25}\right)$ significantly decreased the utilization food, nutritional indicates and some biological aspects. Thus these compounds could be considered as important tools in integrated management programs of Spodoptera littoralis

\section{REFERENCES}

Abbott, M.S. 1925. A method of computing effectiveness of an insecticides. J. Econ. Entomol., 18: 265-267.

Abdel-Hafez, H.F., H.H. Osman. 2013. Effects of pyridalyl and emamectin-benzoate on biological and biochemical parameters of Spodoptera littoralis (Boisd.) and Albino rate. Egypt. Acad. J. Biolog. Sci., 6(3): 59-68.

Abdel-Rahim, E.F., A.M. Azab, M.M. Ali, G.A. Morsi , M.A. Ahmed. 2009. Comparative toxicity of three novel biotic compounds; spinosad, pyridalyl and radical in relative to a conventional insecticides, lannate against the field and laboratory strain of the second and fourth instar larvae of cotton leafworm Spodoptera littoralis (Boisd.). Egypt. J. Agric. Res., 87(2): 433-453.

Abo-Elghar, G.E.S.1993. Influence of abamectin and juvenile hormone analogues on food utilization, ingestion and larval growth of the cotton leafworm, Spodoptera littura(Boisd.). Bull. Ent. Sci.,Egypt Econ. Ser.,20: 173183.

Abo Elghar, G.E.S., H.S.A. Radwan, Z.A. El-Hermawy, L.T.M. Zidan. 1994. Histopathological effects of abamectin, thuringiensis and diflubenzuron on the midgut of Spodoptera littoralis (Lepidoptera Noctuidae) larvae. Bull. Ent. Soc. Egypt., 21: 41-52. 
Abo Elghar, G.E., Z.A. Elbermawy, A.G. Yousef, H.K. Abd Elhaddy. 2005. Monitoring and characterization of insecticide resistance in the cotton leafworm, Spodoptera littoralis (Lepidoptera: Noctuidae). J. Asia. Pacific Entomol. 8: 397-410.

Amer, R.A., A.E. hatem, A.M. Adly. 2012. Effect of emamectin benzoate and pyridalyl on some demographic aspects of pink bollworm, Pectinophora gossypiella (Saunder). Egypt. J. Agric. Res., 90: 657-672.

Aydein, M.H. and M.O. Gurkan. 2006. The efficacy of spinosad on different strains of Spodoptera littoralis (Boisduval) (Lepidoptera: Noctuidae). Turk. J. Biol., 30: 5-9.

Azab, S.G., M.M. Sadek, K. Crailsheim. 2001. Protein metabolism in larvae of the cotton leafworm, Spodoptera llittoralis (Lepidoptera: Noctuidae) and its response to three mycotoxins. J. Econ. Entomol. 30: 817-823.

Chunmei Xu, Zhengqun Zhang, Kaidi Cui, Yunhe Zhao, Jingkun Han, Feng Liu, Wei Mu. 2016. Effects of sublethal concentrations of cyantraniliprole on the development, Fecundity and nutritional physiology of the black cutworm, Agrotis ipsilon (Lepidoptera: Noctuidae).PlosOne e0156555.doi:10.1371/Journal.pone.0156555. 11(6):

Cordova, D., W.A. Benner, J.L. Sacher, J.J. Raugh, J.S. Sopa, G.P. Lahm; T.P. Seby, T.M. Stevenson, L. Flexner; S. Gutteridge, D.F. Rhoades, L. Wu, R.M. Smith,Y. Tao. 2006. Anthranilic diamides: A new class of insecticides with a novel mode of action, ryanodine receptor activation. Pesticide Biochemistry and Physiology, 84: 196-214A.

Crouse, G.D. and T.C. Sparks. 1998. Naturally derived materials as products lead for insect control. The Spinosyns Rev. Toxicol., 2: 133-146.

Crystal,M.M. and L.E. Lachance.1963. The modification of reproduction in insect treated with alkylating agents. Inhibition of ovarian growth and egg reproduction and hatchability . Biol.Bull.,25:270-279.

Dinter, A., K. Brugger, A. Bassi, N.M. Frost, M.D. Woodward. 2008. Chlorantraniliprole (DPX-E2y45, Rynaxypyr) (Coragen 20SC and Altacor 35 WG)- a novel Dupont anthranilic diamide insecticide-demonstrating low toxicity and low risk for beneficial insects and predatory mites. IOBC WPRS Bulletin, 35: 128-135.

Duncan, D. B. 1955. Mutiple range and multiple F test . Biometrics, 11:1-42.

El-Defrawi, M., A. Tippozada, N. Mansour, M. Zeid.1964. Toxicological studies on the Egyptian cotton leafworm Prodenia litura 1-Susceptibility of different level instars to insecticides. J. Econ. Entomol., 57: 591-593.

El-Dewy, M.S.H. 2013. Biological, toxicological potency and field persistence of new insecticides against Spodoptera littoralis (Boisduval).Alex.Sci.Exch.J.34: 306-315.
El-Geddawy, A. R.M,M. A. Ahmed, S. H. Mohamed. 2014. Toxicological evaluation of selected biopesticides and one essential oil in comparison with indoxacarb pesticide on cotton leafworm, Spodoptera littoralis (Boisd.) (Lepidoptera: Noctuidae) under laboratory condition. American-Eurasian J. of Sustainable Agric., 8(2):58-64.

El-Malla, M.A. and E.M.M. Radwan. 2008. Bioresidual toxicity of abamectin and spinosad insecticides on the cotton leafworm Spodoptera littoralis (Boisd.), Bull. Ent. Soc. Egypt, Econ. Ser., 34: 119-129.

El-Naggar, J.B.A. 2013. Sublethal effects of certain insecticides on biological and physiological aspects of Spodoptera littoralis (Boisd.). Nature and Science, 11(17): 19-25.

El-Shazly, N.M. 1993. Quantitative evaluation of food intake and assimilation by Spilostethus pandurus (Scopoli), (Hemiptera: Lygacidae). Bull. Ent. Soc. Egypt, 71: 109117.

El-Sheikh, E.S.A. 2015. Comparative toxicity and sublethal effects of emamectin-benzoate, lufenuron and spinosad on Spodoptera littoralis (Boisd.) (Lepidoptera: Noctuidae). Crop Protection, 67: 228-234.

El-Zahi, E.S. 2013. Field persistence of some novel insecticides residues on cotton plants and their latent effects against Spodoptera littoralis (Boisduval). Alex. Sci. Exch. J. 34(1): 37-43.

Finney, D.J. 1971. Probit Analysis. $3^{\text {rd }}$ ed. Cambridge Univ. Press, London, $318 \mathrm{p}$.

Foster, S.P., I. Denhol., R. Thompson. 2003. Variation in response to Neonicotinoid insecticids in peach potato aphids, Myzus persicae (Homoptera: Aphididae). Pest Manag. Sci., 59(2): 166-173.

Hassan, A. Heba. 2009. Efficiency of some new insecticides on physiological, histological and molecular level of cotton leafworm. Egypt. Acad. J. Biolog. Sci., 2(2): 197209.

Michaud, J.P. and A.K. Grant. 2003. IPM-compatibility of foliar insecticides for citrus indices derived from toxicity to beneficial insects from four orders. J. Insect Sci., 3: 110.

Pavela, R., N. Vrchotova, B. Sera. 2008. Growth inhibitory effect of extracts from Reynoutria sp. plants against Spodoptera littoralis larvae. Agrociencia 42: 573-584.

Pienkowski, R.I. and P.R. Mehring. 1983. Influence of Avermectin B1 and carbofuran on feeding by alfalfa weevil larvae (Coleoptera: Curculionidae). J. Econ. Entomol., 76: 1167-1169.

Rashwan, M.H. 2013. Impact of certain novel insecticides on food utilization ingestion and larval growth of the cotton leafworm, Spodoptera littoralis (Boisd.). New York Sci. J. 6(8): 1-7.

Sakamoto, N. and K. Umeda. 2003. Fine Chemicals, 32(2): 35-44. 
Sakamoto, N., N. U, and Y. Tomighara.2005. Research and development of a novel insecticide "Pyridalyl", "Sumitomo Kagaku: Chem. Abst., 1: 135-144.

Shaurub, E.H., Z.A. Ahmed, E.M. Samica. 1998. Impacts of pyriproxyfen and extracts of Schinus terebinthifolius on development reproduction and reproductive organs in Spodoptera littoralis. J. Egypt Ger. Soc. Zool. E: 57-82.

Slansky, F.J.R. and J.M. Scriber. 1985. Food consumption and utilization( In comprehensive Insect Physiology. Biochemistry and Pharmacology, (Eds. Kerket A. and Gilber, L.I.), Vol. 4, Pergamon Oxford, pp. 87-163.

Slansky, J.F. and J.M. Scriber. 1982. Selected bibliography and summary of qualitative food utilization by immature insects. Bull. Ent. Soc. Amer. 28: 43-55.

Sooho, C.F. and G. Frankel.1966. The consumption and utilization (In comprehensive Insect Physiology, Biochemistry and Pharmacology (eds. Kerket, A. and Gilber, L.I.), Vol. 4, Pergamon, Oxford, pp. 87-163.

Sundaramurthy, V.T. 1977. Effect of inhibition of chitin deposition on the growth and differentiation of to basso caterpillar, Spodoptera litura F. (Noctuidae: Lepidoptera). Z. Pflanzenkrankheith and Pflanzenschutz, 84(10): 597601 .
Van Duyn, J.W. 1971. Investigations concerning host plant resistance to the Mexican bean beetle, Epilachna varivestis in soybean. Ph.D. Dissertation, Clemson Univ., Clemson, USA.

Von Keyserlink, H.C. 1988. The significance of behavior studies in insecticide research. Pestic. Sci., 16: 558-559.

Waldbauer, G.P. 1968. The consumption and utilization of food by insect Adv. Insect Physiol, 5: 229-282.

Wise, J.C., A.B. Coombs, C. Vandervoot, L.J. Gut, E.J. Hoffmann, M.E. Whalon. 2006. Use of residue profile analysis to identify modes of insecticide activity contributing to control of plum curculio in apples. J. Econ. Entomol., 99(6); 2055-2064

Woodering, J.P., C.W. Clifford, R.M. Roe, B.R. Beckman .1978. Effect of $\mathrm{CO}_{2}$ and anoxia on feeding, growth metabolism, water balance and food composition in larval house crickets, Acheta demosticus. J. Insect Physiol., 24: 499-509.

Wright, J.E. 1984. Biological activity of avermectin B1 against the boll weevil (Coleoptera: Curculionidae). J. Econ. Entomol., 77: 1029-1103. 


\section{الملخص العربي \\ تأثير بعض المبيدات الحديثة على الصفات الفسيولوجية والبيولوجية لاودة ورق القطن مديحة الصباحي حامد الديوى}

معامل الاستهلالك ومعدل النهـو ومعــدل تحــول الغــذاء المستهلك و المهضوم داخل جسم الآفة، وعلى العكس مـنـ لهن ذللك لم تؤثر معنويا على معــدل هـــم الغــذاء مقارنـــة

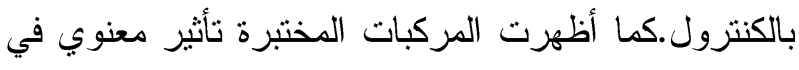

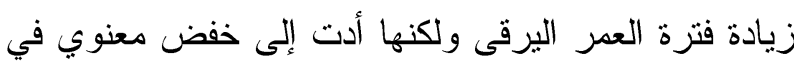

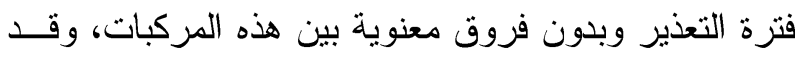

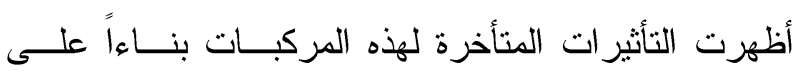
حدوث خفض معنوي في النسبة المئوية للتعـذير لـانير وخروج الفراشات الكاملة وخصوبة البيض الناتج وكـذللك فئل خصوبة الأنثى المعاملة مقارنة بالكنترول. مبيد ســبنتورام

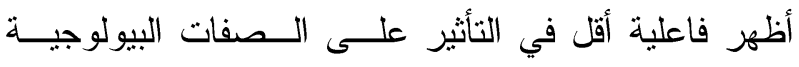

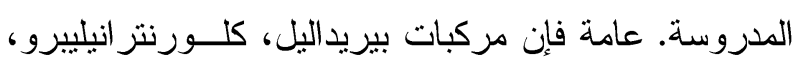

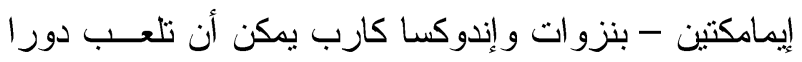

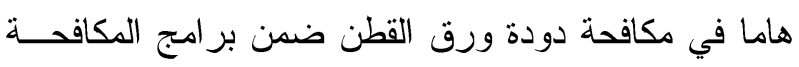

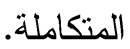

مركبات كلورنتز انيليبرو، بيريــداليل، إندوكـسـاكارب،

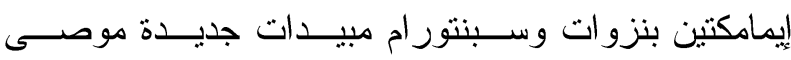

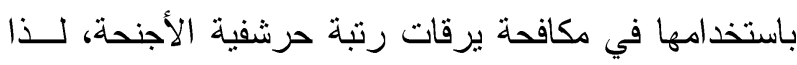

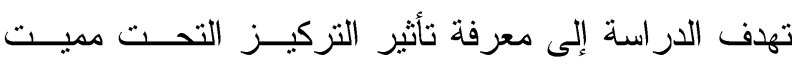
لهذه المركبات على بعض المؤشرات الفسيولوجية ومنها التأثير على معدلات التغذية ودرجة الاســتفادة مسـن بـن

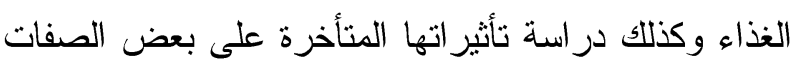
البيولوجية على العمر اليرقى الرابع للسلالة المعملية لدودة

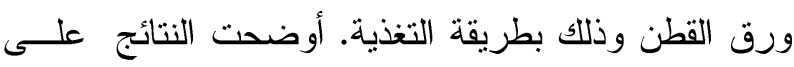
أساس التركيز القاتل ل. ه\% من الأفراد المعاملة أن مبيد

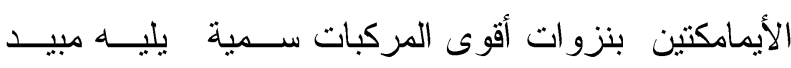

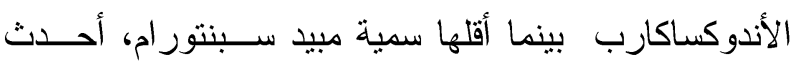
مركبي كلورنتز انيليبرو وبيريداليل تأثير ا متوسط الـسمية.

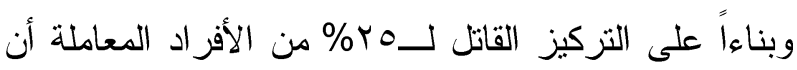

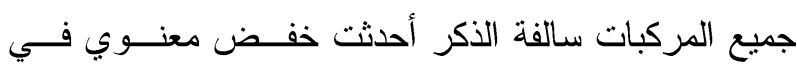

